\title{
PEMBUATAN DAN KARAKTERISASI TINTA SERBUK PRINTER BERBAHAN BAKU ARANG AKTIF DARI LIMBAH PADAT PENGOLAHAN GAMBIR
}

\section{Preparation and Characterization of Printer Toner from Activated Carbon of Solid Waste Processing Gambier}

\author{
Yudo Purnomo*, Salmariza Sy, Hendri Muchtar, dan Robby Kumar \\ Balai Riset dan Standardisasi Industri Padang \\ JI. Raya LIK No. 23 Ulu Gadut Padang, Indonesia \\ *e-mail: yudopurnomo85@gmail.com \\ Diterima: 10 Agustus 2017, revisi akhir: 8 Desember 2017 dan disetujui untuk diterbitkan: 17 Desember 2017
}

\begin{abstract}
ABSTRAK
Penelitian pemanfaatan tanin dan katekin gambir telah banyak dilakukan. Namun, belum dilaporkan penelitian yang mengkaji pemanfaatan limbah padat pengolahan gambir. Tujuan penelitian adalah memanfaatkan limbah padat pengolahan gambir sebagai bahan baku pembuatan tinta serbuk printer. Penelitian dilakukan melalui proses pirolisis limbah padat dengan variasi suhu $400,500,600^{\circ} \mathrm{C}$ dan variasi waktu 30,60 menit. Kadar karbon terikat tertinggi diperoleh sebesar $42 \%$ dengan suhu pirolisis $400^{\circ} \mathrm{C}$ selama 60 menit. Proses pirolisis limbah padat gambir selanjutnya dilakukan pada suhu dan waktu optimal tersebut. Arang aktif dilakukan aktifasi menggunakan aktifator $\mathrm{H}_{3} \mathrm{PO}_{4}$ pada konsentrasi 0,5 dan $10 \%$ selama 24 jam, kemudian didinginkan dan dicuci untuk menghilangkan sisa $\mathrm{H}_{3} \mathrm{PO}_{4}$, dan selanjutnya dikeringkan dalam oven pada suhu $115^{\circ} \mathrm{C}$ selama 24 jam. Proses penghalusan menggunakan ball milling selama 2 jam dengan kecepatan $500 \mathrm{rpm}$. Hasil pengujian kadar karbon terikat berkisar antara 43-51\%. Hasil pengujian morfologi dengan alat Scanning Electron Microscope) memperlihatkan serbuk karbon yang dihasilkan belum mempunyai ukuran seragam. Ukuran partikel serbuk rata-rata 5-10 $\mu \mathrm{m}$ dengan indek polidispersitas sebesar 0,9 . Kandungan unsur mineral yang terbanyak dari hasil analisis serbuk karbon adalah unsur $\mathrm{Ca}, \mathrm{Mg}, \mathrm{K}$, Si, Fe, dan $\mathrm{P}$. Uji coba kualitas cetak berdasarkan ISO/IEC 19752:2004 menggunakan printer laser belum memberikan hasil yang optimal.
\end{abstract}

Kata kunci: gambir, aktifator, serbuk karbon, tinta serbuk

\section{ABSTRACT}

Research on the utilization of tannins and catechins of gambier has been done a lot. There is no research report however that examines the utilization of gambier processing solid waste. The objective of the research was to utilize the solid waste of gambier processing as a raw material of printer toner. The research was done through pyrolysis process of solid waste with temperature variation $400,500,600^{\circ} \mathrm{C}$ and time variation 30,60 minutes. The highest carbon content was obtained $42 \%$ with $400^{\circ} \mathrm{C}$ temperature and 60 minutes. The pyrolysis process of the gambier solid waste was further carried out at the optimum temperature and time. The charcoal was activated with $\mathrm{H}_{3} \mathrm{PO}_{4}$ at concentrations 0; 5; and $10 \%$ for 24 hours, cooled and washed to remove residual of $\mathrm{H}_{3} \mathrm{PO}_{4}$, then drying in the oven at temperature $115^{\circ} \mathrm{C}$ for 24 hours. Size reduction process used a ball milling for 2 hours with speed $500 \mathrm{rpm}$. Fixed carbon content was obtained between $43-51 \%$. The results of morphological testing by scanning electron microscope showed that the produced carbon powder had not a uniform size yet. The average particle size was between 5-10 $\mathrm{mm}$ with polydispersity index 0.9. The most mineral elements of carbon powder analysis using XRF were Ca, Mg, K, Si, Fe, and P. Testing of print quality based on ISO/IEC 19752:2004 using laser jet printers had not provided optimal results yet.

Keywords: gambier, activator, carbon black, powdered toner 


\section{PENDAHULUAN}

Gambir merupakan bahan setengah jadi yang diperoleh dari ekstrak daun dan ranting tanaman gambir (Uncaria gambir Roxb.). Ekstraksi dilakukan secara panas melalui proses perebusan, pengempaan, pengendapan, penirisan, pencetakan, dan pengeringan (Sofyan et al., 2015). Produksi gambir di Sumatera Barat pada tahun 2014 tercatat 17.160 ton dengan luas lahan 32.307 hektar (BPS, 2015).

Sebagian besar gambir di ekspor dalam bentuk gambir mentah (gambir asalan) sehingga hanya sedikit sekali memberi nilai tambah bagi petani dan pertumbuhan industri di Indonesia. Gambir asalan merupakan bahan setengah jadi yang dapat digunakan untuk berbagai keperluan industri, seperti industri makanan, industri farmasi, industri kosmetik, industri pigmen, dan industri lainnya (Kasim, 2011).

Di Sumatera Barat, gambir diolah melalui proses pengempaan secara tradisional. Dalam proses pengempaan dihasilkan limbah padat berupa serpihan daun, oleh petani sekitar dibuang begitu saja dan sebagian dimanfaatkan sebagai pupuk kompos, sehingga dapat dikatakan bahwa limbah padat gambir ini tidak memiliki nilai ekonomis.

Pemanfaatan limbah padat gambir saat ini belum banyak dilaporkan. Penelitian yang telah dilakukan terbatas pemanfatan limbah padat gambir sebagai kompos dan sebagai adsorben pada proses penyerapan limbah (Kasim, 2011). Penelitian ini memanfaatkan limbah padat pengolahan gambir sebagai bahan baku pembuatan toner.

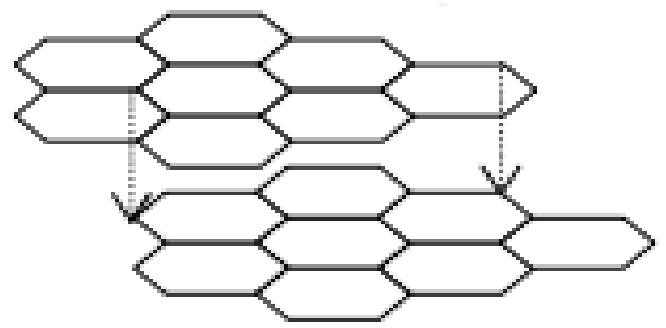

(a)
Toner adalah bahan berbentuk serbuk yang digunakan dalam mesin fotokopi atau printer laser. Pada dasarnya toner terbuat dari bubuk karbon yang dicampur agen pembawa (carrier agent) berupa serbuk besi (iron powder) dengan beberapa bahan aditif seperti stiren akrilat kopolimer, resin hidrokarbon atau bahan lain sehingga meningkatkan kualitas cetak dan daya rekat pada kertas (Mang et al., 2010).

Toner merupakan bubuk yang kompleks berpigmen kering dengan ukuran partikel dari 8-12 mikrometer dan terdiri dari komponen-komponen seperti: polymer, pewarna, agen kontrol pengisi/pembawa, dan beberapa bahan aditif berupa flow control aditif ataupun wax. Polymer umumnya rapuh yang memungkinkan pembuatan partikel menjadi efisien dan titik leleh yang rendah. Pewarna (pigmen, misal karbon hitam) berfungsi untuk memberikan warna toner yang diinginkan. Agen kontrol pengisi/pembawa digunakan untuk mengaktifkan karakteristik magnetik toner (misalnya serbuk besi). Bahan aditif seperti flow control aditif (misalnya karbon silika) digunakan untuk mencegah toner jangan menggumpal dan wax berfungsi mencegah toner menempel pada rol fuser saat dipanaskan (Mang et al., 2010).

Struktur karbon aktif menyerupai struktur grafit. Grafit mempunyai susunan seperti pelat-pelat yang sebagian besar terbentuk dari atom karbon yang berbentuk heksagonal. Jarak antara atom karbon dalam masing-masing lapisan 1,42A. Pada grafit, jarak antara pelat-pelat lebih dekat dan terikat lebih teratur daripada struktur karbon aktif (Suhartana, 2006).

Disajikan pada Gambar 1 yang menunjukkan struktur grafit dan struktur umum karbon aktif.

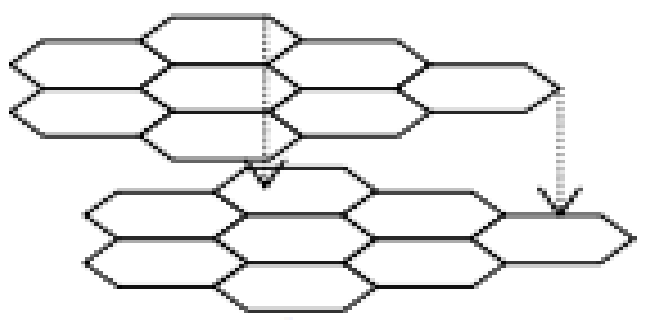

(b)

Gambar 1. Struktur molekul heksagonal grafit (a) dan karbon aktif (b)

Sumber: (Suhartana, 2006) 
Karbon aktif dapat dibuat dari bahan organik maupun anorganik yang mengandung kadar karbon tinggi. Beberapa penelitian dalam pembuatan karbon aktif seperti tempurung kelapa, ampas tebu, serbuk gergaji kayu (Suresh et al., 2010).

Di Indonesia, penelitian pembuatan karbon aktif dari limbah padat organik telah banyak dilakukan antara lain dari: limbah ampas tebu (Asbahani, 2013); kulit ubi kayu (Dewi et al., 2009); limbah cangkang kelapa sawit (Mulyana dan Turmuzi, 2014); limbah daun ketapang (Nopitasari dan Linggawati, 2015); kulit salak (Turmuzi dan Syaputra, 2015). Hal ini dapat diartikan bahwa bahan organik dapat disintesis menjadi karbon aktif, walaupun kebanyakan digunakan sebagai adsorben.

Pembuatan karbon aktif memerlukan tahapan pirolisis bahan baku. Pirolisis sangat bergantung pada suhu dan waktu proses karbonisasi bahan. Bahan baku dengan kerapatan tinggi (seperti tempurung kelapa) membutuhkan suhu tinggi dan waktu lebih lama dibandingkan dengan bahan baku dengan kerapatan rendah (seperti serbuk gergaji kayu) (Kurniaty, 2008).

Karbonisasi/pirolisis merupakan proses dekomposisi thermokimia bahan organik melalui proses pemanasan tanpa atau sedikit oksigen atau pereaksi kimia lainnya, di mana material mentah akan mengalami pemecahan struktur kimia menjadi fase gas. Pirolisis adalah kasus khusus termolisis. Pirolisis ekstrem, yang hanya meninggalkan karbon sebagai residu, disebut karbonisasi. Dalam banyak aplikasi industri, proses ini dilakukan di bawah tekanan dan pada suhu operasi di atas 430 ${ }^{\circ} \mathrm{C}$. Untuk limbah pertanian, misalnya, suhu yang khas adalah $400-600{ }^{\circ} \mathrm{C}$ (Aripin, 2007).

Beberapa penelitian dalam pembuatan toner telah dilakukan seperti pembuatan toner berbahan baku abu ringan (fly ash) (Sugiyanto et al., 2013), dengan penambahan pasir besi (Hasegawa et al., 1999; Mang et al., 2010; Wardani, 2013), ataupun yang dihasilkan dari karbon aktif magnetik limbah tissue (Aripin, 2007).

Oleh sebab itu, bahan utama toner yang berupa karbon memberi peluang bagi limbah padat pengolahan gambir untuk diolah menjadi barang yang mempunyai nilai ekonomi tinggi. Tujuan penelitian adalah memanfaatkan limbah padat pengolahan gambir sebagai bahan baku pembuatan tinta serbuk printer.

\section{METODOLOGI PENELITIAN}

Bahan-bahan yang digunakan adalah limbah padat gambir, asam phospat $\left(\mathrm{H}_{3} \mathrm{PO}_{4}\right)$ teknis, stiren akrilat kopolimer, ferrite powder, dan aquademin. Peralatan yang diperlukan adalah timbangan, crusher, siever, alat pirolisis, wadah steril, ball milling. Pengujian fisika arang aktif menggunakan peralatan uji furnace. Karakterisasi serbuk karbon dievaluasi menggunakan XRF (X-Ray Fluoroescence), SEM (Scanning Electron Microscope), dan PSA (Particle Size Analyzer).

Scanning Electron Microscope (SEM) digunakan untuk memperoleh perbesaran bentuk dan ukuran dari sampel yang jauh lebih tinggi dibandingkan dengan mikroskop konvensional melalui pemusatan berkas cahaya elektron (Julinawati et al., 2015). XRF digunakan untuk identifikasi dan pencacahan karakteristik sinar- $X$ yang terjadi akibat efek fotolistrik dikarenakan elektron dalam atom target pada sampel terkena sinar berenergi tinggi (radiasi gamma, sinar-X) (Wardani, 2013). Sementara pengujian PSA (Particle Size Analyzer) untuk mendapatkan hasil analisa distribusi partikel dengan menganalisis data-size (Z-Average) dan Pdl. Indeks polidispersitas (Pdl) adalah ukuran dari distribusi massa molekul dalam sampel yang menunjukkan keseragaman ukuran, semakin kecil nilai mengindikasikan ukuran yang semakin seragam. Nilai IP lebih kecil dari 0.3 menunjukkan sampel memiliki distribusi ukuran nanopartikel yang semakin sempit dan ukuran diameter nanopartikel makin seragam atau homogen (Masakke et al., 2015).

Penelitian dilakukan dengan variasi konsentrasi aktifator dan penambahan polimer stirene. Aktifator yang digunakan adalah asam phospat $\left(\mathrm{H}_{3} \mathrm{PO}_{4}\right)$ teknis dengan konsentrasi 0 , 5, dan $10 \%$, sedangkan penambahan polimer styrene 
dalam 100 gram serbuk karbon berturutturut $20 \mathrm{~g}, 50 \mathrm{~g}$, dan $60 \mathrm{~g}$. Limbah padat gambir yang digunakan diambil dari sentra gambir di daerah Siguntur Kabupaten Pesisir Selatan Provinsi Sumatera Barat.

\section{Prosedur Penelitian}

\section{Penentuan Suhu Optimum}

Limbah padat gambir dikeringkan kemudian dipotong-potong menggunakan mesin crusher. Untuk mengetahui suhu dan waktu optimum proses pirolisis limbah padat gambir maka dilakukan penelitian pendahuluan dengan memvariasikan suhu pirolisis $400,500,600^{\circ} \mathrm{C}$ dan waktu pirolisis selama 30 menit dan 60 menit. Hasil pirolisis kemudian didinginkan (Mulyana dan Turmuzi, 2014). Arang aktif dilakukan pengujian kadar karbon terikat untuk melihat hasil optimum dari variasi perlakuan.

\section{Proses Aktifasi}

Proses aktifasi dilakukan dengan aktifator asam pospat $\left(\mathrm{H}_{3} \mathrm{PO}_{4}\right)$ pada beberapa konsentrasi, yaitu 0,5 , dan $10 \%$. Selanjutnya dikeringkan dalam oven pada suhu $115^{\circ} \mathrm{C}$ selama 24 jam. Arang aktif dilakukan pencucian untuk menghilangkan sisa $\mathrm{H}_{3} \mathrm{PO}_{4}$, tujuannya agar dihasilkan serbuk karbon yang bebas dari pengotor (Mulyana dan Turmuzi, 2014).

Arang aktif selanjutnya dihaluskan dan diayak dengan ayakan 400 mesh. Arang aktif yang telah lolos ayakan ditambahkan dengan ferrite powder. Perbandingan serbuk karbon aktif dengan ferrite powder adalah $80 \mathrm{~g}$ : $20 \mathrm{~g}$. Dilanjutkan dengan melakukan proses penghalusan menggunakan ball milling. Proses ini dilakukan selama 2 jam dengan kecepatan alat 500 rpm (Sugiyanto et al., 2013). Arang aktif kemudian dilakukan pengujian berupa pengujian fisika (kadar air, abu, volatille matter, dan karbon terikat).

Arang aktif kemudian dipolimerisasi untuk meningkatkan kualitas cetak dan daya rekat serbuk toner serta meningkatkan kemampuan elektrostatis/ magnetik dari serbuk karbon. Polimerisasi dilakukan dengan mencampur serbuk karbon dan polimer stiren akrilat pada tiga tingkat konsentrasi, yaitu polimer : serbuk karbon (20 g : $80 \mathrm{~g}$ ), polimer : serbuk karbon (50 g : $50 \mathrm{~g}$ ), polimer : serbuk karbon ( $60 \mathrm{~g}: 40 \mathrm{~g}$ ). Selanjutnya dilakukan karakterisasi serbuk karbon yang telah dipolimerisasi menggunakan alat XRF, SEM, dan PSA. Tahapan terakhir, dilakukan ujicoba kualitas cetak terhadap serbuk toner yang dihasilkan.menggunakan printer laser dan toner cartridge yang telah disiapkan berdasarkan ISO/IEC 19752: 2004.

\section{HASIL DAN PEMBAHASAN}

\section{Penentuan Suhu Optimum}

Untuk menentukan suhu optimum proses pirolisis dilakukan pengujian kadar karbon terikat terhadap variasi suhu. Tabel 1 disajikan jenis perlakuan suhu dan waktu pirolisis limbah padat gambir.

Tabel 1. Pengaruh suhu dan waktu karbonisasi terhadap kadar karbon terikat

\begin{tabular}{ccc}
\hline \multirow{2}{*}{ Suhu $\left({ }^{\circ} \mathrm{C}\right)$} & \multicolumn{2}{c}{ Kadar Karbon Terikat (\%) } \\
\cline { 2 - 3 } & \multicolumn{2}{c}{ Waktu (Menit) } \\
\cline { 2 - 3 } & 30 & 60 \\
\hline 400 & 33,84 & 42,62 \\
\hline 500 & 36,62 & 36,08 \\
\hline 600 & 32,44 & 29,99 \\
\hline
\end{tabular}

Dari Tabel 1 tampak bahwa suhu optimum proses pirolisis adalah suhu 400 ${ }^{\circ} \mathrm{C}$ selama 60 menit, dengan kadar karbon terikat sebesar $42,62 \%$. Pada suhu pirolisis diatas $400{ }^{\circ} \mathrm{C}$ akan terjadi penurunan kadar karbon terikat. Bentuk arang aktif akan menjadi abu akibat massa/fraksi karbon yang berkurang. Pengarangan merupakan pembakaran biomassa tanpa adanya kehadiran oksigen. Sehingga yang terlepas hanya bagian volatile matter, sedangkan karbonnya tetap karena karbon tidak akan terjadi pembakaran jika tanpa oksigen $\left(\mathrm{O}_{2}\right)$. Temperatur pengarangan berpengaruh terhadap arang yang dihasilkan sehingga penentuan temperatur yang tepat akan menentukan kualitas arang (Sutiyono, 2002).

\section{Analisis Fisika Serbuk Arang Aktif}

Analisis fisika serbuk arang aktif dilakukan berdasarkan SNI 06-3730-1995 
tentang arang aktif teknis. Hasil uji arang aktif pada suhu pirolisis $40{ }^{\circ} \mathrm{C}$ berupa kadar air, kadar volatile matter, kadar abu, dan kadar karbon terikat disajikan pada tabel 2 .

Tabel 2. Hasil pengujian fisika serbuk arang aktif hasil aktivasi

\begin{tabular}{lccc}
\hline \multirow{2}{*}{$\begin{array}{c}\text { Parameter } \\
\text { Pengujian }\end{array}$} & \multicolumn{3}{c}{ Konsentrasi Aktifator (\%) } \\
\cline { 2 - 4 } & 0 & 5 & 10 \\
\hline Kadar Air (\%) & 2.84 & 3.69 & 4.39 \\
\hline Kadar VM (\%) & 45.92 & 42.93 & 39.88 \\
\hline Kadar Abu (\%) & 7.75 & 5.33 & 4.84 \\
\hline $\begin{array}{l}\text { Kadar Karbon } \\
\text { Terikat (\%) }\end{array}$ & 43.48 & 48.04 & 50.92 \\
\hline
\end{tabular}

Kadar karbon terikat maksimum dihasilkan dari konsentrasi aktifator $\mathrm{H}_{3} \mathrm{PO}_{4}$ $10 \%$ sebesar $50.92 \%$. Kadar karbon terikat limbah padat gambir ini lebih rendah dari beberapa bahan organik lainnya yang lebih dikenal, antara lain cangkang kelapa sawit 70-75\% (Purwanto dan Sofyan, 2014), cangkang biji ketapang $60-65 \%$ (Surest et al., 2010), dan tempurung kelapa 60-70\% (Suhartana, 2006). Akan tetapi, kadar karbon ini sudah memenuhi persentase kadar karbon sebagai bahan baku pembuatan tinta serbuk printer. Persentase kadar karbon pada beberapa produk tinta serbuk yang beredar di pasaran berkisar antara 40-60\% (Wardani, 2013). Hal ini dapat disebabkan dari material bahan. Walaupun sama-sama berasal dari material organik, tetapi sifat fisik arang tempurung dan arang cangkang sawit yang lebih keras daripada limbah padat gambir menyebabkan kadar karbon dari limbah padat gambir lebih rendah dari kedua material tersebut. Suhu yang dipakai dalam proses karbonisasi juga berpengaruh terhadap karbon yang dihasilkan. Untuk mendapatkan kadar karbon yang tinggi maka peningkatan suhu memiliki peranan penting. Jumlah atom $\mathrm{C}$ (karbon) semakin meningkat seiring dengan meningkatnya temperatur karbonisasi sehingga dapat diklasifikasi makropori, mesopori, dan mikropori. Semakin tinggi temperatur karbonisasi maka pori-pori akan lebih terbentuk dan jumlah karbon yang dihasilkan akan semakin baik (Habibah et al., 2014).
Proses karbonisasi limbah padat gambir hanya dilakukan pada suhu $400{ }^{\circ} \mathrm{C}$ selama 1 jam. Hal ini dikarenakan pada saat percobaan karbonisasi pada suhu 500 ${ }^{\circ} \mathrm{C}$ selama 1 jam, limbah padat gambir sudah berubah menjadi abu putih.

\section{Karakterisasi Serbuk Karbon Menggunakan Scanning Electron Microscope (SEM)}

Penentuan struktur atom dan komposisi kimia suatu mineral diperlukan pengujian dan peralatan yang canggih. Sifat fisik yang sering digunakan untuk mengkarakterisasi suatu mineral antara lain bentuk kristal (form), kilap (luster), warna (colour), garis (streak), kekerasan (hardness), belahan (cleavage), pecahan (fracture) dan berat jenis (specific gravity). Karakterisasi ini tidak memberikan informasi kandungan mineralnya secara detail, sehingga diperlukan alat karakterisasi lain yang dianggap tidak rumit dan memberikan informasi baik sifat fisik dan sifat kimia lainnya dalam waktu yang lebih singkat (Wardani, 2013).

Perlakuan aktifator $\mathrm{H}_{3} \mathrm{PO}_{4} 0 \%$ dengan penambahan polimer sebanyak 60 gram menghasilkan ukuran partikel serbuk yang homogen berkisar antara 6,4 - 12,3 $\mu \mathrm{m}$. Sedangkan partikel serbuk yang tidak homogen berukuran 37,5 $\mu$ m (Gambar 2a). Perlakuan aktifator $\mathrm{H}_{3} \mathrm{PO}_{4} \quad 5 \%$ dengan penambahan polimer sebanyak 60 gram menghasilkan ukuran partikel homogen berkisar antara 6,75 - $15 \mu \mathrm{m}$. Sedangkan partikel yang tidak homogen berukuran 46,4 $\mu \mathrm{m}$ (Gambar 2b). Perlakuan aktifator $\mathrm{H}_{3} \mathrm{PO}_{4} 10 \%$ dengan penambahan polimer sebanyak 60 gram memiliki ukuran partikel homogen berkisar antara 6,7 - 11,5 $\mu \mathrm{m}$. Sedangkan partikel serbuk yang tampak tidak homogen berukuran 31,0 $\mu \mathrm{m}$ (Gambar 2c). Sementara tinta serbuk kontrol (buatan manufaktur) memiliki partikel yang terlihat homogen dengan ukuran berkisar antara 5,9 - 14,1 $\mu \mathrm{m}$ (Gambar 2d).

Dari Gambar 2 (a), (b), (c), dan (d) dapat disimpulkan bahwa morfologi serbuk karbon yang dihasilkan dari limbah padat gambir belum berukuran seragam, masih terdapat partikel yang berukuran lebih 
besar dibanding dengan partikel yang lain. Berbeda dengan morfologi serbuk karbon dari kontrol sampel yang mempunyai ukuran yang seragam (Gambar 2d). Untuk

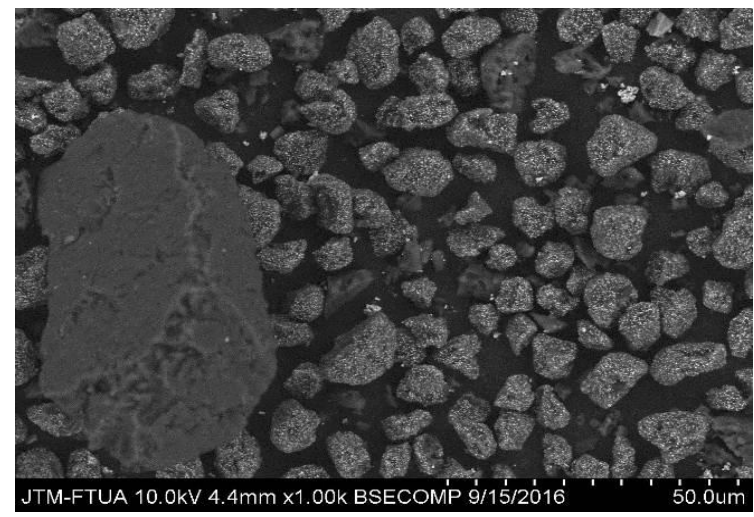

(a)

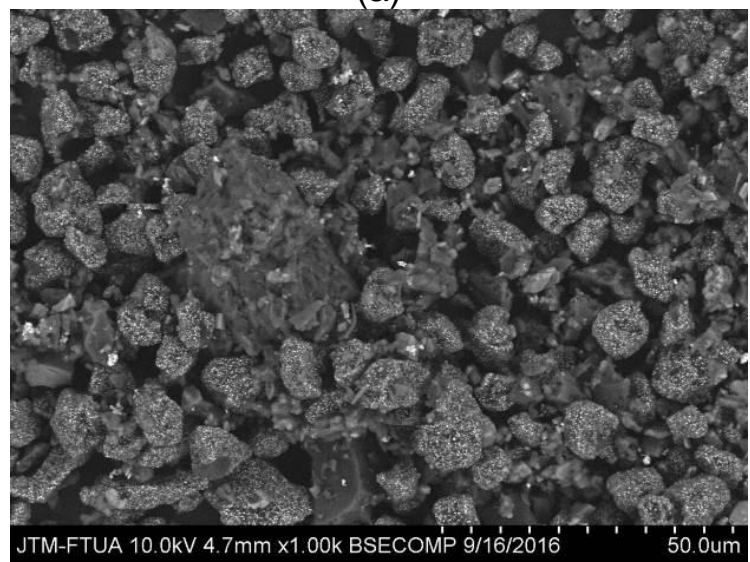

(c) memperoleh distribusi ukuran yang lebih seragam dapat dilakukan dengan menambah waktu penghalusan menggunakan alat ball milling.

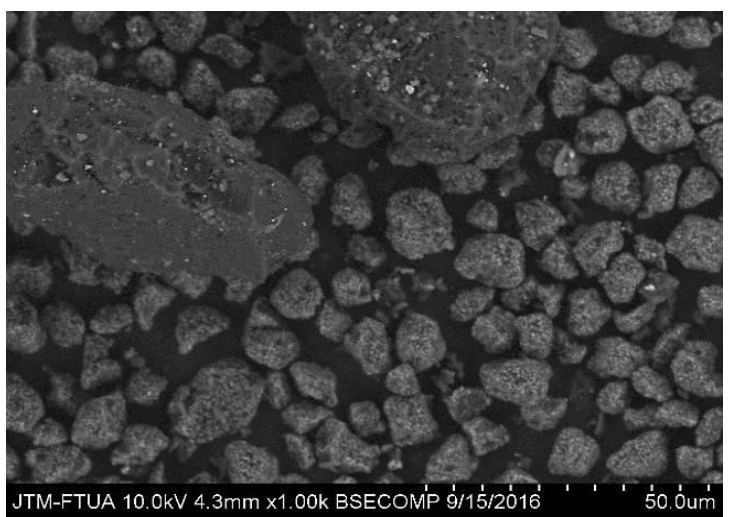

(b)

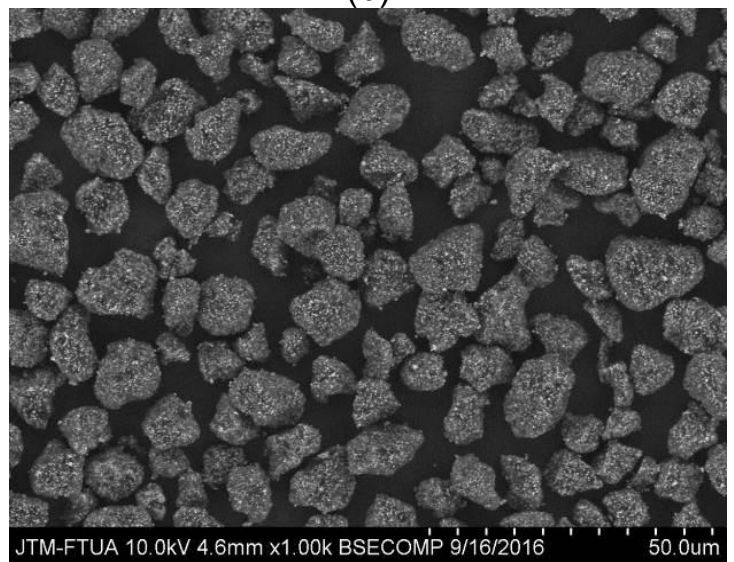

(d)

Gambar 2. Foto SEM morfologi tinta serbuk magnifikasi 1000x kode A1B3 (a), A2B3 (b), A3B3 (3), dan tinta serbuk kontrol (d)

\section{Karakterisasi Serbuk Karbon Menggunakan X-Ray Fluoroescence (XRF)}

Tabel 3 menunjukkan hasil pengujian XRF, diperoleh bahwa serbuk karbon mengandung unsur paduan yang sebagian besar terdiri dari unsur $\mathrm{Ca}, \mathrm{K}, \mathrm{Si}$, Fe, dan $P$. Serbuk karbon dibuat dari bahan organik berupa limbah padat gambir, maka terdapat kandungan logam alkalis ( $\mathrm{Ca}$ dan $\mathrm{K})$ yang lebih tinggi dibandingkan dengan kontrol sampel tinta serbuk komersial.

Pencampuran dengan ferrite powder membuat serbuk karbon memiliki unsur logam $\mathrm{Fe}$ yang berfungsi untuk meningkatkan kemampuan suseptibilitas magnetik serbuk karbon, walaupun kandungan unsur $\mathrm{Fe}$ tersebut masih dibawah kandungan tinta serbuk komersial.

\section{Karakterisasi Serbuk Karbon Menggunakan Particle Size Analyzer (PSA)}

Gambar 3, 4, 5 menunjukkan hasil pengujian distribusi partikel menggunakan Particle Size Analyzer. Dari ketiga gambar, didapatkan nilai IP (Pdl) masing-masing sebesar 0,905, 0,958, dan 0,970. Hal ini dapat diartikan bahwa distribusi ukuran nanopartikel yang masih lebar dan ukuran diameter nanopartikel yang tidak seragam. $\mathrm{Hal}$ ini berbanding lurus dengan hasil pengujian SEM serbuk karbon dimana ukuran partikel terlihat belum homogen. Akan tetapi berbanding terbalik dengan hasil pengujian SEM untuk sampel kontrol tinta serbuk. Gambar 2d memperlihatkan ukuran serbuk karbon yang homogen, tetapi pada pengujian PSA menunjukkan 
nilai IP lebih besar dari 0,3 . Hal ini dapat saja terjadi apabila pemakaian jenis pelarut yang kurang tepat dengan karakter serbuk karbon.

Ukuran partikel serbuk karbon berkisar antara 1194-1885 nm sedangkan partikel serbuk karbon kontrol adalah $1421 \mathrm{~nm}$. Serbuk karbon yang dihasilkan mempunyai ukuran yang memenuhi persyaratan untuk serbuk toner, yaitu antara 8-12 $\mu \mathrm{m}$ (Hasegawa et al., 1999).

Tabel 3. Hasil pengujian XRF (X-Ray Fluoroscence)

\begin{tabular}{cccccc}
\hline \multirow{2}{*}{ Kode Sampel } & \multicolumn{5}{c}{ Coumpound Concentration (\%) } \\
\cline { 2 - 6 } & $\mathrm{Ca}$ & $\mathrm{K}$ & $\mathrm{Si}$ & $\mathrm{Fe}$ & $\mathrm{P}$ \\
\hline A1B1 & 6,89 & 2,06 & 8,86 & 74,19 & 2,18 \\
\hline A1B2 & 2,43 & 0,75 & 7,24 & 80,99 & 0,81 \\
\hline A1B3 & 1,94 & 0,59 & 5,06 & 84,44 & 0,71 \\
\hline A2B1 & 6,42 & 1,63 & 8,52 & 59,93 & 18,36 \\
\hline A2B2 & 2,31 & 0,56 & 5,72 & 77,85 & 7,21 \\
\hline A2B3 & 1,76 & 0,43 & 5,03 & 80,91 & 4,56 \\
\hline A3B1 & 9,84 & 1,07 & - & 47,77 & - \\
\hline A3B2 & 4,68 & 0,51 & 6,43 & 65,43 & 17,52 \\
\hline A3B3 & 3,37 & 0,37 & 4,99 & 74,01 & 10,57 \\
\hline Kontrol 1 & 0,14 & - & 3,46 & 89,99 & 0,26 \\
\hline Kontrol 2 & 0,10 & - & 4,74 & 91,99 & 0,43 \\
\hline
\end{tabular}

Keterangan: $\mathrm{A} 1 \mathrm{~B} 1$ = serbuk toner konsentrasi aktifator $0 \%$ dicampur dengan aditif stirene akrilat 80g/20g; A1B2 = serbuk toner konsentrasi aktifator $0 \%$ dicampur dengan aditif stirene akrilat $50 \mathrm{~g} / 50 \mathrm{~g}$; A1B3 = serbuk toner konsentrasi aktifator $0 \%$ dicampur dengan aditif stirene akrilat $40 \mathrm{~g} / 60 \mathrm{~g}$; A2B1 = serbuk toner konsentrasi aktifator $5 \%$ dicampur dengan aditif stirene akrilat $80 \mathrm{~g} / 20 \mathrm{~g}$; $\mathrm{A} 2 \mathrm{~B} 2=$ serbuk toner konsentrasi aktifator $5 \%$ dicampur dengan aditif stirene akrilat $50 \mathrm{~g} / 50 \mathrm{~g}$; A2B3 = serbuk toner konsentrasi aktifator 5\% dicampur dengan aditif stirene akrilat $40 \mathrm{~g} / 60 \mathrm{~g}$; $\mathrm{A} 3 \mathrm{~B} 1$ = serbuk toner konsentrasi aktifator $10 \%$ dicampur dengan aditif stirene akrilat $80 \mathrm{~g} / 20 \mathrm{~g}$; A3B2 = serbuk toner konsentrasi aktifator $10 \%$ dicampur dengan aditif stirene akrilat $50 \mathrm{~g} / 50 \mathrm{~g}$; A3B3 = serbuk toner konsentrasi aktifator $10 \%$ dicampur dengan aditif stirene akrilat $40 \mathrm{~g} / 60 \mathrm{~g}$

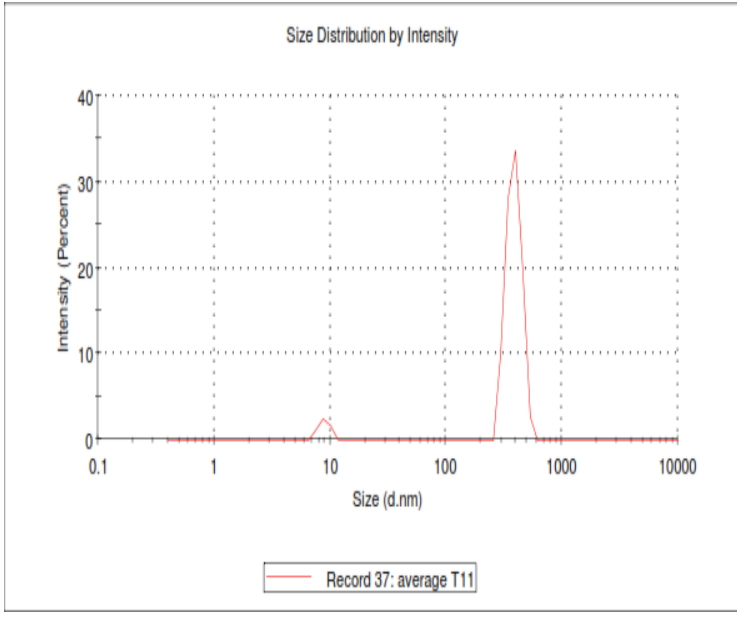

Gambar 3. Hasil analisis PSA kode sampel A2B2

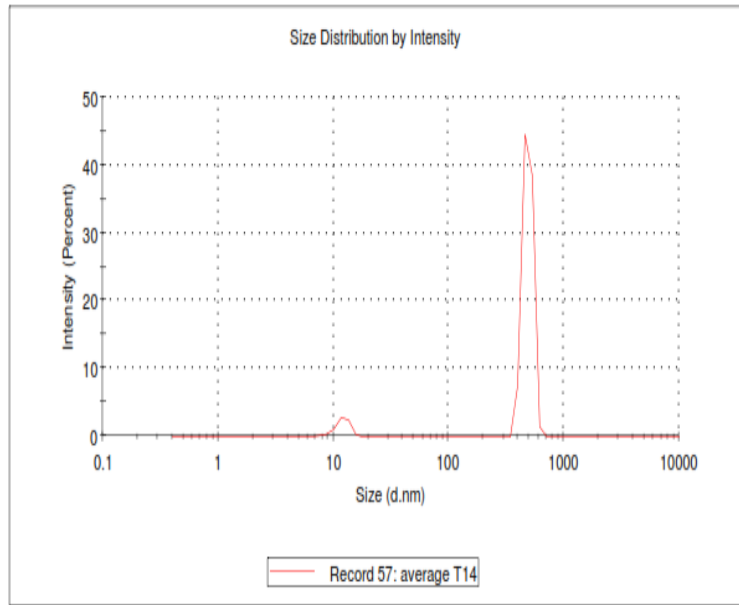

Gambar 4. Hasil analisis PSA kode sampel A3B2 


\section{Ujicoba Serbuk Karbon}

Uji coba dilakukan berdasarkan standar ISO/IEC 19752:2004 Annex E Standard Test Page for Monochrome Toner. Menurut metode uji ISO/IEC 19752:2004, tinta serbuk (toner) dengan pigmen hitam (monochrome) harus dapat melalui uji coba hasil cetakan seperti pada Gambar 6.

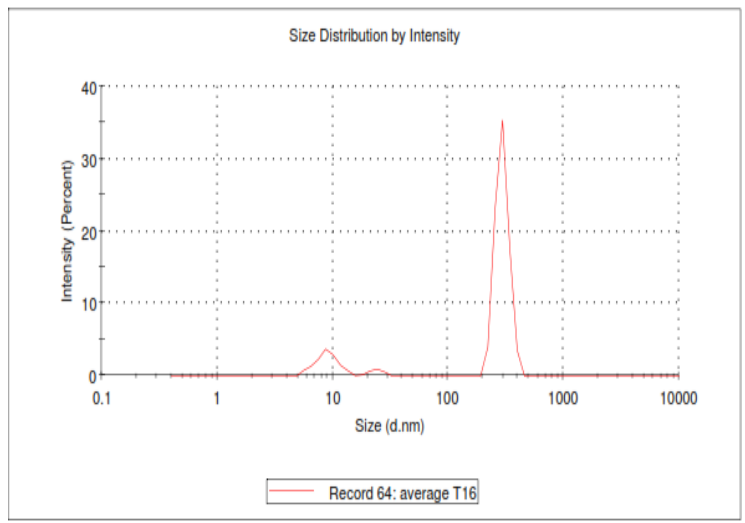

Gambar 5. Hasil analisis PSA kontrol sampel

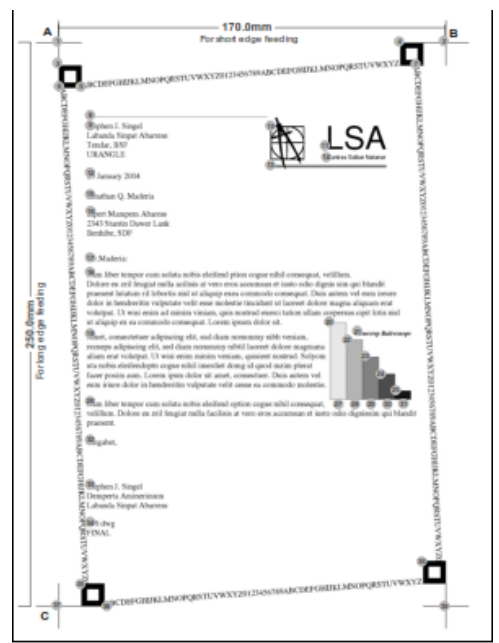

Gambar 6. Standard test page ISO/IEC 19752:2004

Dalam penggunaan 1 (satu) unit cartridge toner dengan rata-rata jumlah tinta serbuk yang diisikan sebanyak 80-100 gram (tergantung merek cartridge), maka harus dapat menghasilkan antara 60008000 halaman pada kondisi suhu $23 \pm 2{ }^{\circ} \mathrm{C}$ dan kelembaban $50 \pm 10 \% \mathrm{RH}$. Dari hasil uji coba tinta serbuk menggunakan sebuah printer laser didapatkan hasil yang tidak memuaskan. Hasil cetakan terlihat kabur sampai halaman 50 (seperti terlihat pada
Gambar 7) dan berangsur menghilang setelah halaman tersebut, artinya serbuk karbon masih sedikit sekali berhasil diproses secara elektrophotograph melewati roller pada cartrdige printer.

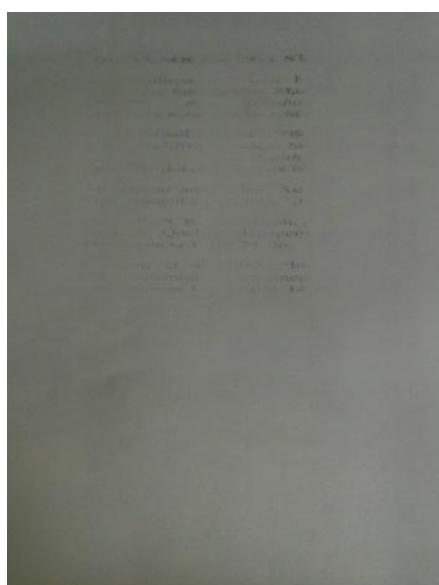

Gambar 7. Hasil cetakan tinta serbuk berbahan baku limbah padat gambir

Beberapa penyebab yang dapat dianalisis antara lain jenis aktifator yang belum tepat, aktifator $\mathrm{H}_{3} \mathrm{PO}_{4}$ dapat menghasilkan serbuk karbon yang bebas dari pengotor, akan tetapi belum dapat membangkitkan kemampuan magnetik dari serbuk karbon. Aktifator yang mengandung unsur logam seperti $\mathrm{FeCl}_{3}$ atau $\mathrm{ZnCl}_{2}$ kemungkinan akan dapat meningkatkan kemampuan magnetik serbuk karbon (Aripin, 2007). Selain itu, ukuran partikel yang belum seragam dan kualitas polimer juga mempengaruhi kemampuan magnetik serbuk karbon yang telah dibuat.

\section{KESIMPULAN}

Dari hasil penelitian, didapatkan bahwa tinta toner dari arang aktif limbah padat pengolahan gambir yang dihasilkan melalui proses pirolisis pada suhu optimum $400{ }^{\circ} \mathrm{C}$ selama 60 menit dengan kadar karbon terikat $42 \%$. Konsentrasi $\mathrm{H}_{3} \mathrm{PO}_{4}$ yang terbaik dalam proses aktifasi selama 2 jam pada suhu $105{ }^{\circ} \mathrm{C}$ adalah 10\% dengan hasil uji kadar karbon terikat $50,92 \%$, kadar abu 4,84\%, kadar VM $39,80 \%$ dan kadar air 4,39\%. Hasil pengujian morfologi dengan alat SEM memperlihatkan serbuk karbon yang dihasilkan dari limbah padat pengolahan gambir belum mempunyai ukuran seragam. 
Ukuran partikel serbuk yang terkecil adalah sebesar $1194 \mathrm{~nm}$ dengan indek polidispersitas sebesar 0,90. Sedangkan kandungan unsur yang terbanyak dari hasil analisis serbuk karbon menggunakan XRF adalah unsur $\mathrm{Ca}, \mathrm{Mg}, \mathrm{K}, \mathrm{Si}$, Fe, dan $\mathrm{P}$. Uji coba kualitas cetak menggunakan printer laser Jet dan cartridge belum memberikan hasil yang optimal.

\section{UCAPAN TERIMA KASIH}

Kami sampaikan terima kasih kepada Heru Febra dan Dia Sari Permata atas kerjasamanya yang telah membantu pelaksanaan penelitian.

\section{DAFTAR PUSTAKA}

Aripin, 2007. Preparasi dan karakterisasi karbon aktif magnetik nanopori. J. Fis. dan Apl. 3, 1-3.

Asbahani, 2013. Pemanfaatan limbah ampas tebu sebagai karbon aktif untuk menurunkan kadar besi pada air sumur. J. Tek. Sipil UNTAN 13, 105114.

BPS, 2015. Sumatera Barat dalam angka. Badan Pusat Statistik Provinsi Sumatera Barat, Padang.

Dewi, T.K., Nurrahman, A., Permana, E., 2009. Pembuatan karbon aktif dari kulit ubi kayu (Mannihot esculenta). J. Tek. Kim. 16, 24-30.

Habibah, M.D., Nurdiana, H., Rohmawati, L., Setyarsih, W., 2014. Sintesis nanopori karbon aktif dari tempurung kluwak (Pangium edule). Pros. Semin. Nas. Fis. dan Pendidik. Fis. ke-5 5, 30-32.

Hasegawa, J., Yanagida, N., Tamura, M., 1999. Toner prepared by the direct polymerization method in comparison with the pulverization method. Colloids Surfaces A Physicochem. Eng. Asp. 153, 215-220. doi:10.1016/S09277757(98)00445-2

Julinawati, Niaci, S., Sholih, R., 2015. Karakterisasi batuan aceh menggunakan Scanning Electron Microscope-Energy Dispersive X-Ray
(SEM-EDX) dan X-Ray Difraction (XRD). J. Kim. Unsyiah 1-7.

Kasim, A., 2011. Proses produksi dan industri hilir gambir. Andalas University Press, Padang.

Kurniaty, E., 2008. Pemanfaatan cangkang kelapa sawit sebagai arang aktif. J. Penelit. Ilmu Tek. 8, 96-103.

Mang, M.E., Chang, H., Cox, G.P., Leonardo, J.L., 2010. Toner additive. US Patent No. 7,678,215.

Masakke, Y., Sulfikar, Rasyid, M., 2015. Biosintesis partikel-nano perak menggunakan ekstrak metanol daun manggis (Garcinia mangostana L.). J. Sainsmat IV, 28-41.

Mulyana, E., Turmuzi, M., 2014. Aplikasi karbon aktif dari cangkang kelapa sawit dengan aktifator $\mathrm{H}_{3} \mathrm{PO}_{4}$ untuk penyerapan logam berat $\mathrm{Cd}$ dan $\mathrm{Pb}$. J. Tek. Kim. USU 3, 5-10.

Nopitasari, N., Linggawati, A., 2015. Karbonisasi limbah daun ketapang untuk biosorpsi $\mathrm{Cr}$ (vi) dalam air. Ind Che Acta 5, 30-35.

Purwanto, D., Sofyan, 2014. Pengaruh suhu dan waktu pengarangan terhadap kualitas briket arang dari limbah tempurung kelapa sawit. J. Litbang Ind. 4, 29-38.

Sofyan, Failisnur, Salmariza, 2015. Pengaruh perlakuan limbah dan jenis mordan kapur, tawas, dan tunjung terhadap mutu pewarnaan kain sutera dan katun menggunakan limbah cair gambir (Uncaria gambir Roxb). J. Litbang Ind. 5, 79-89.

Sugiyanto, A., Zulaikah, S., Mufti, N., 2013. Pengaruh lama milling terhadap suseptibilitas magnetik dan morfologi toner berbahan baku abu ringan (fly ash), karbon, dan polimer. J. Fis. Univ. Negeri Malang 1-6.

Suhartana, 2006. Pemanfaatan tempurung kelapa sebagai bahan baku arang aktif dan aplikasinya untuk penjernihan air sumur di desa belor kecamatan ngaringan kabupaten grobogan. Berk. Fis. FMIPA UNDIP 9, 151-156. 
Suresh, S., Srivastava, V.C., Mishra, I.M., 2010. Isotherm, thermodynamics, desorption, and disposal study for the adsorption of catechol and resorcinol onto granular activated carbon. J. Chem. Eng. Data 56, 811-818. doi:10.1021/je100303x

Surest, A., Permana, I., Wibisono, R.G., 2010. Pembuatan karbon aktif dari cangkang biji ketapang. Jur. Tek. Kim. UNSRI 3, 1-11.

Sutiyono, 2002. Pembuatan briket arang dari tempurung kelapa dengan bahan pengikat tetes tebu dan tapioka. J. Kim. dan Teknol. 5, 1-10.

Turmuzi, M., Syaputra, A., 2015. Pengaruh suhu dalam pembuatan karbon aktif dari kulit salak (Salacca Edulis) dengan impregnasi asam fosfat $\left(\mathrm{H}_{3} \mathrm{PO}_{4}\right)$. J. Tek. Kim. USU 4, 42-46.

Wardani, P.Y., 2013. Sintesis dan karakterisasi tinta serbuk (toner) berbahan baku pasir besi menggunakan XRD dan SEM-EDAX. Universitas Negeri Malang. 